\title{
Association of Selenium and Risk of Esophageal Cancer: A Review
}

\author{
Ommolbanin Younesian (PhD \\ Candidate) \\ Department of Clinical Biochemistry, \\ School of Medicine, Golestan \\ University of Medical Sciences, \\ Gorgan, Iran \\ Samareh Younesian (PhD \\ Candidate) \\ Department of Haematology and blood \\ banking, Shahid Beheshti University of \\ Medical Sciences, Tehran, Iran \\ Sara Hosseinzadeh (MSc) \\ Department of Laboratory Medicine, \\ Faculty of Paramedical Sciences, \\ Golestan University of Medical \\ Sciences, Gorgan, Iran \\ Hamid Reza Joshaghani (PhD) \\ Metabolic Disorders Research Center, \\ Golestan University of Medical \\ Sciences, Gorgan, Iran \\ Corresponding author: Hamid Reza \\ Joshaghani \\ Email: joshaghani@goums.ac.ir.com \\ Tel: +989111779909 \\ Address: Department of Laboratory \\ Medicine, Faculty of Paramedical \\ Sciences, Golestan University of \\ Medical Sciences, Gorgan, Iran \\ Received: 18 Jul 2019 \\ Revised: 05 Aug 2019 \\ Accepted: 19 Aug 2019

\section{(c) (i) \&} \\ This work is licensed under a Creative \\ Commons Attribution 4.0 License.
}

\begin{abstract}
Esophageal cancer (EC) is one of the most common types of cancer, especially in Asia. Esophageal squamous cell cancer (ESCC) is the most important histological subtype of EC, which accounts for $90 \%$ of all EC cases worldwide. ESCC is highly prevalent in Turkey, Iran, Kazakhstan and northern and central parts of China. Selenium is an essential micronutrient that is required for cellular functioning and synthesis of several selenoproteins. It also modulates the antioxidant defense system, cell cycle and apoptosis. This article reviews the most important molecular mechanisms of EC and investigates the association between selenium level and incidence of EC in high-risk areas.
\end{abstract}

Keywords: Esophageal cancer, selenium, selenoprotein.

This paper should be cited as: Younesian $O$, Younesianin S, Hosseinzadeh S, Joshaghani HR [Association of Selenium and Risk of Esophageal Cancer: A Review]. mljgoums. 2020; 14(1): 1-9 


\section{INTRODUCTION}

Esophageal cancer (EC) is one of the most common types of cancer, especially in Asia. In 2018, 572,034 new cases of EC and 508,585 EC-related deaths were recorded worldwide (1). The highest mortality rates among men are 14.1 per 100,000 in eastern Asia and 12.8 per 100,000 in southern Africa, while the highest mortality rates for women are 7.3 per 100,000 in eastern Asia and 6.2 per 100,000 in southern Africa (2). The high-risk areas for EC are in the "Asian EC Belt" consisting of countries such as Turkey, Iran, Kazakhstan and China (3). According to recent reports, of 35,000 cancer-related deaths in Iran, 5,800 cases have had EC (4). Esophageal cancer occurs in the tissue lining of the interior surface or epithelium of the esophagus. There are two main histological subtypes of EC: esophageal squamous cell carcinomas (ESCC) and esophageal adenocarcinomas (EAC) (5). Based on epidemiological studies, various factors including gender, obesity, alcohol consumption, smoking, gastroesophageal reflux disease, Helicobacter pylori infection, $\mathrm{N}$-nitroso compounds, toxins and micronutrient deficiency may increase the risk of developing EC (6-13). In countries such as the United States, Australia and Western Europe where EAC is the predominant histological subtype (14), obesity, tobacco use, low intake of fruits and vegetables and gastroesophageal reflux disease are the most important risk factors. The annual incidence rate of ESCC is over 100 cases per 100,000 people in countries such as China, Iran and Turkey. In these countries, tobacco and alcohol consumption, low intake of fruits and vegetables, low socioeconomic status and genetic predisposition are known risk factors of ESCC (15). Generally, ESCC is more common in men $(69 \%)$ than in women $(31 \%)$, but the incidence rates varies widely in highand low-risk areas (16). The highest rate of ESCC and gastric cardia adenocarcinoma is reported from Taihung Mountain range of China and northeastern Iran (17). Previous studies have reported a significant inverse correlation between serum selenium levels and the risk of ESCC. In the high-risk areas of China, selenium deficiency was the main risk factor for ESCC $(18,19)$. However, in highrisk areas of Iran (such as Golestan Province), the association of dietary selenium intake with risk of ESCC was nonlinear and possibly
U-shaped (20). The aim of the present review is to examine association of selenium and risk of EC while focusing on the molecular mechanism of this cancer.

\section{Molecular mechanism of EC}

The incidence and progression of EC are a multistep process accompanied with activation of oncogenes and inactivation of tumor suppressor genes $(21,22)$. It has been demonstrated that EC progression is strongly linked with cell proliferation, survival, invasion, metastasis and angiogenesis, cell adhesion, the imbalance of oncogene and tumor suppressor gene expression and participation of the immune system. Key pathways associated with EC occurrence and development are PI3K-Akt signaling pathway, MAPK signaling pathway, cell adhesion pathways and p53 signaling pathway. In addition, increased levels of interleukin 8 and $\mathrm{C}-\mathrm{X}-\mathrm{C}$ chemokine receptor type 7 play a main role in the pathogenesis of EC (23). It has been reported that overexpression of phosphorylated ERK1/2 is associated with several clinical and pathologic factors in $\operatorname{ESCC}(24,25)$. Recent studies show that Rh family, C glycoprotein (RHCG) is mostly downregulated in primary ESCC in contrast with their corresponding normal mucosa $(26,27)$. Moreover, nuclear transcription factor- $\kappa \mathrm{B}(\mathrm{NF}-\mathrm{\kappa B}) / \mathrm{p} 65$-mediated increased expression of MMP1 and MMP9 contributes to tumorigenicity and metastasis in $\operatorname{ESCC}(28,29)$. In addition, RHCG can act as a new tumor suppressor gene in the progression of ESSC by decreasing I $\mathrm{I} B$ phosphorylation and inhibiting NF- $\mathrm{BB} / \mathrm{p} 65$ activation (30). Alcohol consumption also increases the risk of developing ESCC (31) mainly through disruption of DNA methylation (32). LINE-1 hypomethylation, a substitute marker of global hypomethylation, has been proposed as an important phenomenon that can contribute to ESCC (33-35). Long non-coding RNAs (lncRNAs) are both oncogenic and cancer suppressive (36). Overexpression of lncRNA $X$ inactivate-specific transcript (XIST) has been detected in EC tissues and cell lines. This lncRNA can play an oncogenic role in the EC progression by sponging miR-494 and controlling CDK6 expression (37). CDC7, a serine/threonine kinase, plays an essential role in the initiation of DNA replication and DNA damage $(38,39)$. Studies have shown that CDC7 was remarkably upregulated in ESCC 
tissues, and depletion of CDC7 can prevent cell proliferation and induce apoptosis in ESSC cells (40).

\section{Nutritional aspects of selenium}

Selenium is an essential trace element that was first discovered by Jöns Jakob Berzelius in 1817. Although initially known as a toxic compound (41), selenium has been recognized as an important micronutrient since the 1950s (42). Selenium is present in various organic and inorganic chemical forms. The organic chemical form is found mostly in food, but inorganic selenium is mainly found in water and air (43). Organic forms of selenium (such as selenocysteine and selenomethionine) and inorganic compounds such as selenate and selenite are absorbed through the intestinal lumen and converted to selenide for selenoproteins (SePs) synthesis or selenosugar for elimination (44). To date, twenty-five SePs genes have been identified in humans (45). Most SePs, including glutathione peroxidase (GPx) and thioredoxin reductase (TrxR) family of proteins are involved in the antioxidant defense system. Other mechanisms related to SePs include control of apoptosis, modulation of immune system, synthesis of thyroid hormones and deoxyribonucleoside triphosphates, reduction of oxidized proteins, selenium transport and storage, protein folding and degradation of misfolded proteins in the endoplasmatic reticulum (46). Various studies suggest that insufficient levels of selenium and SePs are related to cancer $(46,47)$. Because of the inhibitory effects of selenium on tumor cells, this compound can be used to prevent tumorigenesis (48).

\subsection{Selenium and antioxidant defense systems}

Oxidative stress occurs when the production of free radicals, such as reactive oxygen species (ROS), reactive nitrogen species (RNS, e.g. nitric oxide, NO) as well as oxidised lipids and proteins overbalances an organism's antioxidant abilities, which leads to cell/tissue damage (49). Reactive oxygen species-induced DNA damage can trigger carcinogenesis and cancer progression (50-52). Glutathione peroxidase and thioredoxin reductase are responsible for redox homeostasis and neutralization of peroxides and other electrophiles (53, 54). The glutathione peroxidase family consists of eight known glutathione peroxidases (GPx1-8). In humans, GPx1, GPx2, GPx3, GPx4 and GPx6 contain selenocysteine, whereas GPx5, GPx7 and
GPx8 have cysteine instead of selenocysteine. This family of proteins protects membrane lipids and macromolecules against the oxidative damage generated by peroxides through conversion of hydrogen peroxide to water by utilization of glutathione (GSH) as an electron donor $\left(\mathrm{H}_{2} \mathrm{O}_{2}+2 \mathrm{GSH} \rightarrow \mathrm{GS}-\mathrm{SG}+\right.$ $\left.2 \mathrm{H}_{2} \mathrm{O}\right)(55,56)$. The most abundant member of this family is GPx1, which is generally expressed in cytosol and mitochondria of different tissues (57). Expression of this protein is directly linked to selenium levels (58). This GPx can prevent oxidative DNA damage and prevent tumorigenesis in the initiation phase (59). Since GPx2 is solely expressed in the gastrointestinal tract (60), it might have protective effects against oxidative damage (61). Overexpression of GPx2 has been reported in neoplastic transformation of squamous epithelial cells (62) and Barrett's esophagus (63). Furthermore, GPx2 was remarkably overexpressed in ESCC tumor tissues compared with non-tumor tissues. Thus, GPx2 can be an important prognostic factor in ESCC patients (64). While GPx3, a plasma antioxidant enzyme, its expression is reduced in ESCC tissues and ESCC cell lines, and through the FAK/AKT pathway, it inhibits tumor gene in ESCC (65). It is proposed that low selenium levels might increase GPx2 expression, decrease GPx1 expression, but does not alter GPx4 expression (66). Thioredoxin reductase (TrxR) enzymes consisting of TrxR1, 2 and 3 reduce thioredoxins and play a role in the reduction of selenite, selenodiglutathione and methylseleninate. Hence, the TrxR family plays a vital role in selenium metabolism (6769). In addition, TrxR expression is necessary for maintenance of redox balance and many tumor suppression pathways. For instance, TrxR1 boost maturation of $\mathrm{p} 53$, inactive forms of protein kinase $\mathrm{C}$ and phosphatase and tensin homolog (70-72). Selenoprotein W (SEPW1) contains a single selenocysteine residue at its active site and has been reported to have glutathione-dependent antioxidant activity in vivo (73).

\subsection{Selenium and cell cycle regulation}

Cyclins, cyclin dependent kinases (CDKs) and CDK inhibitors are cell cycle regulators (74). Selenocysteine reduces the expression of cyclin $\mathrm{A}$, thus inducing $\mathrm{S}$ phase cell cycle arrest via ROS-mediated DNA damage and controlling the MAPKs and AKT signaling 
pathways (75). Selenoprotein $\mathrm{W}$ is the only selenoprotein whose mRNA was increased by sub-micromolar concentrations of selenium in cultured human cells (76). It may control cell cycle via several mechanisms. Selenoprotein W promotes cell cycle progression by regulating the dissociation of 14-3-3 from CDC25B (77). Moreover, SEPW1 silencing increases p53 level by reducing proteasomal degradation of $\mathrm{p} 53$, induces $\mathrm{p} 21$ expression and prevents G1/S transition (78). SELENOH is a selenium-sensitive SePs with a disturbed expression under suboptimal selenium concentrations. Unlike GPx2, TXNRD1 and SELENOF, knockdown of SELENOH improves cell proliferation in vitro and promotes tumor growth in vivo, indicating that SELENOH may suppress tumor progression (79-82). SELENOH affect cell cycle through inhibition of G1/S transition by modulating p21 and CCNE1 expression $(83,84)$. The 15$\mathrm{kDa}$ selenoprotein (Sep15) can also contribute to cancer progression (85-89). A study reported that Sep15-deficient Chang liver cells are arrested at the G1 phase by upregulation of p21 and p27 (82). Both p21 and p27 inhibit cell cycle progression by interacting with cyclins and CDKs (90).

\subsection{Selenium and apoptosis}

At low concentrations, selenium exerts antioxidant effects by suppressing apoptosis and inhibiting oxidative stress (91). In high concentrations, selenium acts as a prooxidant and hence could contribute to the fight against cancer cells (92-96). Pharmacological doses of selenium compounds stimulate apoptosis in cancer cells through p53-dependent pathways (97-100). Sodium selenite induces apoptosis via ROS-mediated inhibition of NF- $\mathrm{KB}$ signaling, increases $\mathrm{Bax}$ expression and reduces expression of anti-apoptotic proteins, such as Bcl-2 (101). Selenomethionine can lead to apoptosis and prevent the growth of cancer cells by significantly reducing level of $\beta$-catenin and c-Myc expression. In addition, selenomethionine can suppress growth of cancer cells through mechanisms related to Wnt/ $\beta$-catenin pathway (102). Methylseleninic acid strongly inhibits the growth of ESCC cell lines by promoting $\beta$-catenin degradation through ubiquitin-proteasome pathway (103).

\section{Association of EC and selenium}

Several studies have investigated the correlation between selenium and EC. In a high-risk area for EC in Iran (Golestan
Province), there was a significant positive association between selenium levels in the soil and EC incidence rates (104). Another study in the Golestan Province showed that total selenium content in soil, grain, loess and sediments is higher in high-risk areas for EC. However, this study indicated that selenium deficiency does not play a main role in the etiology of EC in the Golestan Province (17, 105). A significant positive correlation was found between selenium level in rice seeds and EC rates in the Golestan Province. These results propose that selenium levels in soil and rice might be involved in the pathogenesis of EC (106). Another study in a high-risk area of Iran revealed a U-shaped association between selenium intake and incidence of ESCC (20). Cohort studies in the Netherlands revealed an inverse association between selenium level in the toenail and risk of ESSC (107). However, a case-control study in the Golestan Province did not find such correlation (108). In a Chinese population, low dietary selenium intake was found as a major risk factor for ESSC (109), especially in smokers and heavy drinkers with p53 Pro/Pro and GSTP1 Ile/Ile genotypes (110). In southeastern Iran, serum selenium level was significantly lower in cancer patients than in healthy individuals (111). Furthermore, there was a significant positive correlation between serum selenium level and occurrence of esophageal squamous dysplasia in East Africa, a high-risk area for incidence of ESCC (112).

\section{CONCLUSION}

Findings suggest that GPx3, TrxR1 and SELENOH can prevent cancer progression, while GPx2, SEPW1 and Sep15 promote cancer progression. Several studies in highrisk areas for EC demonstrated that both selenium deficiency and increased selenium level could alter the risk of developing ECs. Further research is needed to understand the molecular mechanisms related to the association of selenium with EC.

\section{ACKNOWLEDGMENTS}

The authors would like to thank the Golestan University of Medical Sciences, Iran.

\section{CONFLICT OF INTEREST}

The authors declare that there is no conflict of interest. 


\section{REFERENCES}

1. Bray F, Ferlay J, Soerjomataram I, Siegel RL, Torre LA, Jemal A. Global cancer statistics 2018: GLOBOCAN estimates of incidence and mortality worldwide for 36 cancers in 185 countries. CA Cancer J Clin. 2018; 68(6): 394-424. doi: 10.3322/caac.21492.

2. Torre LA, Bray F, Siegel RL, Ferlay J, Lortet-Tieulent J, Jemal A. Global cancer statistics, 2012. CA Cancer J Clin. 2015; 65(2): 87-108. doi: 10.3322/caac. 21262.

3. Pennathur A, Gibson MK, Jobe BA, Luketich JD. Oesophageal carcinoma. Lancet. 2013; 381(9864): 40012.

4. Sadjadi A, Nouraie M, Mohagheghi MA, MousaviJarrahi A, Malekezadeh R, Parkin DM. Cancer occurrence in Iran in 2002, an international perspective. Asian Pac J Cancer Prev. 2005; 6(3): 359-63.

5. Yu Y, Taylor PR, Li J-Y, Dawsey SM, Wang G-Q, Guo W-D, et al. Retrospective cohort study of riskfactors for esophageal cancer in Linxian, People's Republic of China. Cancer Causes \& Control. 1993;4(3):195-202.

6. Palladino-Davis A, Mendez B, Fisichella P, Davis C. Dietary habits and esophageal cancer. Dis Esophagus. 2015; 28(1): 59-67. doi: 10.1111/dote.12097.

7. Joshaghani H, Badiei F, Roshandel G, Sedaghat M, Tazik A, Kiaei M, et al. Vitamin D Deficiency in High and Low Risk Populations for Esophageal Cancer in Northern Iran. Basic Clin Cancer Res. 2018; 10(4): 2631.

8. Keszei AP, Goldbohm RA, Schouten LJ, Jakszyn P, van den Brandt PA. Dietary N-nitroso compounds, endogenous nitrosation, and the risk of esophageal and gastric cancer subtypes in the Netherlands Cohort Study. Am J Clin Nutr. 2013; 97(1): 135-46. doi: 10.3945/ajen.112.043885.

9. Joshaghani H, Amiriani $\mathrm{T}$, Vaghari $\mathrm{G}$, Besharat $\mathrm{S}$, Molana A, Badeleh $\mathrm{M}$, et al. Effects of omeprazole consumption on serum levels of trace elements. $\mathrm{J}$ Trace Elem Med Biol. 2012; 26(4): 234-7. doi: 10.1016/j.jtemb.2012.02.002.

10. Taherizadeh M, Khoshnia M, Shams S, Joshaghani H. Comparison of Plasma Taurine Levels between Patients with Esophageal Cancer and Healthy Controls. mljgoums. 2017; 11(2) :1-4. DOI: 10.18869/acadpub.mlj.11.2.1

11. Ghasemi-Kebria F, Joshaghani H, Taheri NS, Semnani S, Aarabi M, Salamat F, et al. Aflatoxin contamination of wheat flour and the risk of esophageal cancer in a high risk area in Iran. Cancer Epidemiol. 2013; 37(3): 290-3. doi: 10.1016/j.canep.2013.01.010.

12. Namjoo M, Salamat F, Rajabli N, HAJIHOSEEINI R, Niknejad F, Kohsar F, et al. Quantitative determination of aflatoxin by high performance liquid chromatography in wheat silos in Golestan province, north of Iran. Iran J Public Health. 2016; 45(7): 905-10.

13. Joshaghani H, Mirkarimi H-s, Besharat S, Roshandel G, Sanaei O, Nejabat M. Comparison of the serum levels of trace elements in areas with high or low rate of esophageal cancer. Middle East J Dig Dis. 2017; 9(2): 81-85. doi: 10.15171/mejdd.2017.55.
14. Chung CS, Lee YC, Wu MS. Prevention strategies for esophageal cancer: Perspectives of the East vs. West. Best Pract Res Clin Gastroenterol. 2015; 29(6): 869-83. doi: 10.1016/j.bpg.2015.09.010.

15. Domper Arnal MJ, Ferrandez Arenas A, Lanas Arbeloa A. Esophageal cancer: Risk factors, screening and endoscopic treatment in Western and Eastern countries. World J Gastroenterol. 2015; 21(26): 7933-43. doi: 10.3748/wjg.v21.i26.7933.

16. Arnold M, Soerjomataram I, Ferlay J, Forman D. Global incidence of oesophageal cancer by histological subtype in 2012. Gut. 2015; 64(3): 381-7. doi: 10.1136/gutjnl-2014-308124.

17. Islami F, Kamangar F, Aghcheli K, Fahimi S, Semnani S, Taghavi N, et al. Epidemiologic features of upper gastrointestinal tract cancers in Northeastern Iran. Br J Cancer. 2004; 90(7): 1402-6.

18. Mark SD, Qiao YL, Dawsey SM, Wu YP, Katki H, Gunter EW, et al. Prospective study of serum selenium levels and incident esophageal and gastric cancers. $\mathbf{J}$ Natl Cancer Inst. 2000; 92(21): 1753-63.

19. Wei WQ, Abnet CC, Qiao YL, Dawsey SM, Dong $\mathrm{ZW}$, Sun XD, et al. Prospective study of serum selenium concentrations and esophageal and gastric cardia cancer, heart disease, stroke, and total death. Am J Clin Nutr. 2004; 79(1): 80-5.

20. Hashemian M, Poustchi H, Abnet CC, Boffetta P, Dawsey SM, Brennan PJ, et al. Dietary intake of minerals and risk of esophageal squamous cell carcinoma: results from the Golestan Cohort Study-3. Am J Clin Nutr. 2015; 102(1): 102-8. doi: 10.3945/ajen.115.107847.

21. Montesano R, Holestein M, Hainaui P. Genetic alterations in esophageal cancer and their relevance to etiology and pathogenesis: a review. International journal of cancer. 1996; 69(3): 225-35.

22. Ahmadian N, Pashaei-Asl R, Samadi N, RahmatiYamchi M, Rashidi M-R, Ahmadian M, et al. Hesa-a effects on cell cycle signaling in esophageal carcinoma cell line. Middle East J Dig Dis. 2016; 8(4): 297-302.

23. Yue Y, Song M, Qiao Y, Li P, Yuan Y, Lian J, et al. Gene function analysis and underlying mechanism of esophagus cancer based on microarray gene expression profiling. Oncotarget. 2017; 8(62): 105222-105237. doi: 10.18632/oncotarget.22160.

24. Wang H, Zhang Y, Yun H, Chen S, Chen Y, Liu Z. ERK expression and its correlation with STAT1 in esophageal squamous cell carcinoma. Oncotarget. 2017; 8(28): 45249-45258. doi: 10.18632/oncotarget.16902.

25. Cui X, Li S, Li T, Pang X, Zhang S, Jin J, et al. Significance of elevated ERK expression and its positive correlation with EGFR in Kazakh patients with esophageal squamous cell carcinoma. Int J Clin Exp Pathol. 2014; 7(5): 2382-2391.

26. Handlogten ME, Hong S-P, Zhang L, Vander AW, Steinbaum ML, Campbell-Thompson M, et al. Expression of the ammonia transporter proteins $R h B$ glycoprotein and $R h C$ glycoprotein in the intestinal tract. Am J Physiol Gastrointest Liver Physiol. 2005; 288(5): G1036-47. 
27. Chen B-S, Xu Z-X, Xu X, Cai Y, Han Y-L, Wang J, et al. RhCG is downregulated in oesophageal squamous cell carcinomas, but expressed in multiple squamous epithelia. Eur J Cancer. 2002; 38(14): 1927-36.

28. Wang F, He W, Fanghui P, Wang L, Fan Q. NF- $\kappa B P$ 65 promotes invasion and metastasis of oesophageal squamous cell cancer by regulating matrix metalloproteinase-9 and epithelial-to-mesenchymal transition. Cell biology international. 2013; 37(8): 780-8.

29. Liu M, Hu Y, Zhang M-F, Luo K-J, Xie X-Y, Wen J, et al. MMP1 promotes tumor growth and metastasis in esophageal squamous cell carcinoma. Cancer letters. 2016; 377(1): 97-104.

30. Ming X-Y, Zhang X, Cao T-T, Zhang L-Y, Qi J-L, Kam N-W, et al. RHCG Suppresses Tumorigenicity and Metastasis in Esophageal Squamous Cell Carcinoma via Inhibiting NF- $\kappa B$ Signaling and MMP1 Expression. Theranostics. 2018; 8(1): 185.

31. Bravi F, Edefonti V, Randi G, Garavello W, La Vecchia C, Ferraroni M, et al. Dietary patterns and the risk of esophageal cancer. Ann Oncol. 2012; 23(3): 76570. doi: 10.1093/annonc/mdr295.

32. Seitz HK, Stickel F. Molecular mechanisms of alcohol-mediated carcinogenesis. Nat Rev Cancer. 2007; 7(8): 599-612.

33. Hoshimoto S, Takeuchi H, Ono S, Sim MS, Huynh JL, Huang SK, et al. Genome-Wide Hypomethylation and Specific Tumor-Related Gene Hypermethylation are Associated with Esophageal Squamous Cell Carcinoma Outcome. J Thorac Oncol. 2015 Mar;10(3):509-17. doi: 10.1097/JTO.0000000000000441.

34. Baba Y, Watanabe M, Murata A, Shigaki H, Miyake $\mathrm{K}$, Ishimoto T, et al. LINE-1 hypomethylation, DNA copy number alterations, and CDK6 amplification in esophageal squamous cell carcinoma. Clin Cancer Res. 2014; 20(5): 1114-24. doi: 10.1158/1078-0432.CCR-131645.

35. Iwagami S, Baba Y, Watanabe M, Shigaki H, Miyake $\mathrm{K}$, Ishimoto $\mathrm{T}$, et al. LINE-1 hypomethylation is associated with a poor prognosis among patients with curatively resected esophageal squamous cell carcinoma. Ann Surg. 2013; 257(3): 449-55. doi: 10.1097/SLA.0b013e31826d8602.

36. Gibb EA, Brown CJ, Lam WL. The functional role of long non-coding RNA in human carcinomas. Molecular cancer. 2011 ; 10(1): 38. doi: 10.1186/1476-4598-10-38.

37. Chen Z, Hu X, Wu Y, Cong L, He X, Lu J, et al. Long non-coding RNA XIST promotes the development of esophageal cancer by sponging miR-494 to regulate CDK6 expression. Biomed Pharmacother. 2019; 109: 2228-2236. doi: 10.1016/j.biopha.2018.11.049.

38. Sclafani R, Holzen T. Cell cycle regulation of DNA replication. Annu Rev Genet. 2007; 41: 237-80. doi: 10.1146/annurev.genet.41.110306.130308.

39. Labib K. How do Cdc7 and cyclin-dependent kinases trigger the initiation of chromosome replication in eukaryotic cells? Genes Dev. 2010; 24(12): 1208-19. doi: 10.1101/gad.1933010.

40. Cao J-X, Lu Y. Targeting CDC7 improves sensitivity to chemotherapy of esophageal squamous cell carcinoma. Onco Targets Ther. 2019; 12: 63-74.doi: 10.2147/OTT.S183629.
41. Franke KW. A new toxicant occurring naturally in certain samples of plant foodstuffs. 1. Results obtained in preliminary feeding trials. Journal of Nutrition. 1934; 8(5): 597-608.

42. Schwarz K, Foltz CM. Selenium as an integral part of factor 3 against dietary necrotic liver degeneration. Nutrition. 1999; 15(3): 255.

43. Harbison RD, Bourgeois MM, Johnson GT. Hamilton and Hardy's industrial toxicology: John Wiley \& Sons; 2015.

44. Ohta Y, Suzuki KT. Methylation and demethylation of intermediates selenide and methylselenol in the metabolism of selenium. Toxicol Appl Pharmacol. 2008; 226(2): 169-77.

45. Gladyshev VN, Arner ES, Berry MJ, Brigelius-Flohe $\mathrm{R}$, Bruford EA, Burk RF, et al. Selenoprotein Gene Nomenclature. J Biol Chem. 2016 Nov 11;291(46):24036-24040.

46. Roman M, Jitaru P, Barbante C. Selenium biochemistry and its role for human health. Metallomics. 2014; 6(1): 25-54. doi: 10.1039/c3mt00185g.

47. Hsueh YM, Su CT, Shiue HS, Chen WJ, Pu YS, Lin $\mathrm{YC}$, et al. Levels of plasma selenium and urinary total arsenic interact to affect the risk for prostate cancer. Food Chem Toxicol. 2017; 107(Pt A): 167-175. doi: 10.1016/j.fct.2017.06.031.

48. Wu M, Kang MM, Schoene NW, Cheng W-H. Selenium compounds activate early barriers of tumorigenesis. J Biol Chem. 2010; 285(16): 1205512062. doi: 10.1074/jbc.M109.088781.

49. Barrett CW, Short SP, Williams CS. Selenoproteins and oxidative stress-induced inflammatory tumorigenesis in the gut. Cell Mol Life Sci. 2017; 74(4): 607-616. doi: 10.1007/s00018-016-2339-2.

50. Dreher D, Junod AF. Role of oxygen free radicals in cancer development. Eur J Cancer. 1996; 32(1): 30-8.

51. Cooke MS, Evans MD, Dizdaroglu M, Lunec J. Oxidative DNA damage: mechanisms, mutation, and disease. FASEB J. 2003;17(10):1195-214.

52. Takebe G, Yarimizu J, Saito Y, Hayashi T, Nakamura $\mathrm{H}$, Yodoi J, et al. A comparative study on the hydroperoxide and thiol specificity of the glutathione peroxidase family and selenoprotein $P$. J Biol Chem. 2002; 277(43): 41254-8.

53. Huang $\mathrm{Z}$, Rose $\mathrm{AH}$, Hoffmann PR. The role of selenium in inflammation and immunity: from molecular mechanisms to therapeutic opportunities. Antioxid Redox Signal. 2012; 16(7): 705-43. doi: 10.1089/ars.2011.4145.

54. Mattmiller S, Carlson BA, Sordillo L. Regulation of inflammation by selenium and selenoproteins: impact on eicosanoid biosynthesis. J Nutr Sci. 2013; 2: e28. doi: 10.1017/jns.2013.17.

55. Margis R, Dunand C, Teixeira FK, Margis-Pinheiro M. Glutathione peroxidase family-an evolutionary overview. FEBS J. 2008; 275(15): 3959-70. doi: 10.1111/j.1742-4658.2008.06542.x.

56. Maiorino FM, Brigelius-Flohé R, Aumann K, Roveri A, Schomburg D, Flohé L. Diversity of glutathione peroxidases. Methods Enzymol. 1995; 252: 38-53. 
57. Lubos E, Loscalzo J, Handy DE. Glutathione peroxidase-1 in health and disease: from molecular mechanisms to therapeutic opportunities. Antioxid Redox Signal. 2011; 15(7): 1957-97. doi: 10.1089/ars.2010.3586.

58. Barnes KM, Evenson JK, Raines AM, Sunde RA. Transcript analysis of the selenoproteome indicates that dietary selenium requirements of rats based on seleniumregulated selenoprotein $m R N A$ levels are uniformly less than those based on glutathione peroxidase activity. J Nutr. 2008; 139(2): 199-206.

59. Baliga MS, Wang H, Zhuo P, Schwartz JL, Diamond AM. Selenium and GPX-1 overexpression protect mammalian cells against $U V$-induced DNA damage. Biol Trace Elem Res. 2007; 115(3): 227-41.

60. Chu F-F, Doroshow J, and, Esworthy R. Expression, characterization, and tissue distribution of a new cellular selenium-dependent glutathione peroxidase, GSHPX-GI. J Biol Chem. 1993; 268(4): 2571-6.

61. Brigelius-Flohé R. Tissue-specific functions of individual glutathione peroxidases. Free Radic Biol Med. 1999; 27(9-10): 951-65.

62. Serewko MM, Popa C, Dahler AL, Smith L, Strutton $\mathrm{GM}$, Coman W, et al. Alterations in gene expression and activity during squamous cell carcinoma development. Cancer res. 2002; 62(13): 3759-65.

63. Mörk H, Scheurlen M, Al-Taie O, Zierer A, Kraus M, Schöttker K, et al. Glutathione peroxidase isoforms as part of the local antioxidative defense system in normal and Barrett's esophagus. Int J Cancer. 2003; 105(3): 3004.

64. Lei Z, Tian D, Zhang C, Zhao S, Su M. Clinicopathological and prognostic significance of GPX2 protein expression in esophageal squamous cell carcinoma. BMC cancer. 2016; 16(1): 410.

65. Zhu X, Wang J, Li L, Deng L, Wang J, Liu L, et al. GPX3 suppresses tumor migration and invasion via the FAK/AKT pathway in esophageal squamous cell carcinoma. Am J Transl Res. 2018; 10(6): 1908.

66. Wingler $\mathrm{K}$, Böcher $\mathrm{M}$, Flohé L, Kollmus $\mathrm{H}$, Brigelius-Flohé R. mRNA stability and selenocysteine insertion sequence efficiency rank gastrointestinal glutathione peroxidase high in the hierarchy of selenoproteins. Euro J Biochem. 1999; 259(1-2): 149-57.

67. Björnstedt M, Kumar S, Holmgren A. Selenodiglutathione is a highly efficient oxidant of reduced thioredoxin and a substrate for mammalian thioredoxin reductase. J Biol Chem. 1992; 267(12): 8030-4.

68. Gromer S, Gross JH. Methylseleninate is a substrate rather than an inhibitor of mammalian thioredoxin reductase Implications for the antitumor effects of selenium. Journal of Biological Chemistry. 2002; 277(12): 9701-6

69. Kumar S, Björnstedt M, Holmgren A. Selenite is a substrate for calf thymus thioredoxin reductase and thioredoxin and elicits a large non-stoichiometric oxidation of NADPH in the presence of oxygen. European journal of biochemistry. 1992; 207(2): 435-9.

70. Kahlos K, Zhang J, Block ER, Patel JM. Thioredoxin restores nitric oxide-induced inhibition of protein kinase $C$ activity in lung endothelial cells. Molecular and cellular biochemistry. $2003 ; 254(1-2)$ : 47-54.
71. Lee S-R, Yang K-S, Kwon J, Lee C, Jeong W, Rhee SG. Reversible inactivation of the tumor suppressor PTEN by H2O2. J Biol Chem. 2002; 277(23): 20336-42.

72. Moos PJ, Edes K, Cassidy P, Massuda E, Fitzpatrick FA. Electrophilic prostaglandins and lipid aldehydes repress redox-sensitive transcription factors p53 and hypoxia-inducible factor by impairing the selenoprotein thioredoxin reductase. Journal of Biological Chemistry. 2003; 278(2): 745-50.

73. Jeong D-w, Kim TS, Chung YW, Lee BJ, Kim IY. Selenoprotein $W$ is a glutathione-dependent antioxidant in vivo. FEBS Lett. 2002; 517(1-3): 225-8.

74. Tula-Sanchez AA, Havas AP, Alonge PJ, Klein ME, Doctor SR, Pinkston W, et al. A model of sensitivity and resistance to histone deacetylase inhibitors in diffuse large B cell lymphoma: Role of cyclin-dependent kinase inhibitors. Cancer biology \& therapy. 2013; 14(10): 94961.

75. Wang K, Fu X-t, Li Y, Hou Y-j, Yang M-f, Sun J-y, et al. Induction of s-phase arrest in human glioma cells by selenocysteine, a natural selenium-containing agent via triggering reactive oxygen species-mediated DNA damage and modulating MAPKs and AKT pathways. Neurochem Res. 2016; 41(6): 1439-47. doi: 10.1007/s11064-016-1854-8.

76. Hawkes WC, Wang TT, Alkan Z, Richter BD, Dawson K. Selenoprotein W modulates control of cell cycle entry. Biol Trace Elem Res. 2009; 131(3): 229-44. doi: 10.1007/s12011-009-8367-0.

77. Park YH, Jeon YH, Kim IY. Selenoprotein W promotes cell cycle recovery from $G 2$ arrest through the activation of CDC25B. Biochimica et Biophysica Acta (BBA)-Molecular Cell Research. 2012; 1823(12): $2217-$ 26.

78. Hawkes WC, Printsev I, Alkan Z. Selenoprotein W depletion induces a p53-and p21-dependent delay in cell cycle progression in RWPE-1 prostate epithelial cells. $\mathrm{J}$ Cell Biochem. 2012; 113(1): 61-9. doi: 10.1002/jcb.23328.

79. Banning A, Kipp A, Schmitmeier S, Löwinger M, Florian S, Krehl S, et al. Glutathione peroxidase 2 inhibits cyclooxygenase-2-mediated migration and invasion of HT-29 adenocarcinoma cells but supports their growth as tumors in nude mice. Cancer Res. 2008; 68(23): 9746-53. doi: 10.1158/0008-5472.CAN-08-1321. 80. Yoo M-H, Xu X-M, Carlson BA, Gladyshev VN, Hatfield DL. Thioredoxin reductase 1 deficiency reverses tumor phenotype and tumorigenicity of lung carcinoma cells. J Biol Chem. 2006; 281(19): 13005-8.

81. Irons R, Tsuji PA, Carlson BA, Ouyang P, Yoo M-H, $\mathrm{Xu} \mathrm{X}-\mathrm{M}$, et al. Deficiency in the 15-kDa selenoprotein inhibits tumorigenicity and metastasis of colon cancer cells. Cancer Prev Res (Phila). 2010; 3(5): 630-9. doi: 10.1158/1940-6207.CAPR-10-0003.

82. Bang J, Huh JH, Na J-W, Lu Q, Carlson BA, Tobe R, et al. Cell proliferation and motility are inhibited by $G 1$ phase arrest in 15-kDa selenoprotein-deficient Chang liver cells. Mol Cells. 2015; 38(5): 457-65. doi: 10.14348/molcells.2015.0007.

83. Bertz M, Kühn K, Koeberle SC, Müller MF, Hoelzer $\mathrm{D}$, Thies K, et al. Selenoprotein $H$ controls cell cycle progression and proliferation of human colorectal cancer cells. Free Radic Biol Med. 2018; 127: 98-107. doi: 10.1016/j.freeradbiomed.2018.01.010. 
84. Nakanishi M, Adami GR, Robetorye RS, Noda A, Venable SF, Dimitrov D, et al. Exit from G0 and entry into the cell cycle of cells expressing p21Sdil antisense RNA. PNAS. 1995; 92(10): 4352-6.

85. Gladyshev VN, Jeang K-T, Wootton JC, Hatfield DL. A new human selenium-containing protein purification, characterization, and cDNA sequence. $\mathrm{J}$ Biol Chem. 1998; 273(15): 8910-5.

86. Nasr M, Hu Y, Diamond A. Allelic loss at the Sep 15 locus in breast cancer. Cancer Ther. 2004; 1: 293-8.

87. Kumaraswamy E, Malykh A, Korotkov KV, Kozyavkin S, Hu Y, Kwon SY, et al. Structureexpression relationships of the $15-k D a$ selenoprotein gene possible role of the protein in cancer etiology. $\mathrm{J}$ Biol Chem. 2000; 275(45): 35540-7.

88. Tsuji PA, Carlson BA, Naranjo-Suarez S, Yoo M-H, $\mathrm{Xu} \mathrm{X}-\mathrm{M}$, Fomenko DE, et al. Knockout of the $15 \mathrm{kDa}$ selenoprotein protects against chemically-induced aberrant crypt formation in mice. PLoS One. 2012; 7(12): e50574.

89. Tsuji PA, Naranjo-Suarez S, Carlson BA, Tobe R, Yoo M-H, Davis CD. Deficiency in the $15 \mathrm{kDa}$ selenoprotein inhibits human colon cancer cell growth. Nutrients. 2011; 3(9): 805-17. doi: 10.3390/nu3090805.

90. Sherr CJ, Roberts JM. CDK inhibitors: positive and negative regulators of G1-phase progression. Genes dev. 1999; 13(12): 1501-12.

91. Fan C, Jiang J, Yin X, Wong K-H, Zheng W, Chen T. Purification of selenium-containing allophycocyanin from selenium-enriched Spirulina platensis and its hepatoprotective effect against $t$ - $\mathrm{BOOH}$-induced apoptosis. Food chemistry. 2012; 134(1): 253-61.

92. Fan C, Chen J, Wang Y, Wong Y-S, Zhang Y, Zheng $\mathrm{W}$, et al. Selenocystine potentiates cancer cell apoptosis induced by 5-fluorouracil by triggering reactive oxygen species-mediated DNA damage and inactivation of the ERK pathway. Free Radic Biol Med. 2013; 65: 305-316. doi: 10.1016/j.freeradbiomed.2013.07.002.

93. Fan C, Zheng W, Fu X, Li X, Wong Y, Chen T. Enhancement of auranofin-induced lung cancer cell apoptosis by selenocystine, a natural inhibitor of TrxR1 in vitro and in vivo. Cell Death Dis. 2014; 5: e1191. doi: 10.1038/cddis.2014.132.

94. Chen T, Wong Y-S. Selenocystine induces reactive oxygen species-mediated apoptosis in human cancer cells. Int J Biochem Cell Biol. 2009; 41(3): 666-76. doi: 10.1016/j.biocel.2008.07.014.

95. Chen T, Wong Y-S. Selenocystine induces caspaseindependent apoptosis in MCF-7 human breast carcinoma cells with involvement of $p 53$ phosphorylation and reactive oxygen species generation. Int $\mathrm{J}$ Biochem Cell Biol. 2009; 41(3): 666-76. doi: 10.1016/j.biocel.2008.07.014.

96. Chen T, Wong Y. Selenocystine induces apoptosis of A375 human melanoma cells by activating ROSmediated mitochondrial pathway and p53 phosphorylation. Cell Mol Life Sci. 2008; 65(17): 276375. doi: 10.1007/s00018-008-8329-2.

97. Lanfear J, Fleming J, Wu L, Webster G, Harrison PR. The selenium metabolite selenodiglutathione induces p53 and apoptosis: relevance to the chemopreventive effects of selenium? Carcinogenesis. 1994; 15(7): 1387-92.
98. Jiang C, Hu H, Malewicz B, Wang Z, Lü J. Seleniteinduced p53 Ser-15 phosphorylation and caspasemediated apoptosis in LNCaP human prostate cancer cells. Molecular cancer therapeutics. 2004; 3(7): 877-84.

99. Goel A, Fuerst F, Hotchkiss E, Boland CR. Selenomethionine induces p53 mediated cell cycle arrest and apoptosis in human colon cancer cells. Cancer biology \& therapy. 2006; 5(5): 529-35.

100. Guan L, Huang F, Li Z, Han B, Jiang Q, Ren Y, et al. P53 transcription-independent activity mediates selenite-induced acute promyelocytic leukemia NB4 cell apoptosis. BMB Rep. 2008; 41(10): 745-50.

101. Zhang T, Zhao G, Zhu X, Jiang K, Wu H, Deng G, et al. Sodium selenite induces apoptosis via ROSmediated NF-kappaB signaling and activation of the Bax-caspase-9-caspase-3 axis in $4 T 1$ cells. $\mathrm{J}$ Cell Physiol. 2019; 234(3): 2511-2522. doi: 10.1002/jcp.26783.

102. Korbut E, Ptak-Belowska A, Brzozowski T. Inhibitory effect of selenomethionine on carcinogenesis in the model of human colorectal cancer in vitro and its link to the Wnt/beta-catenin pathway. Acta Biochim Pol. 2018; 65(3): 359-366. doi: 10.18388/abp.2018_2628.

103. Zhang W, Yan S, Liu M, Zhang G, Yang S, He S, et al. $\beta$-catenin/TCF pathway plays a vital role in selenium induced-growth inhibition and apoptosis in esophageal squamous cell carcinoma (ESCC) cells. Cancer letters. 2010; 296(1): 113-22.

104. Semnani S, Roshandel G, Zendehbad A, Keshtkar A, Rahimzadeh H, Abdolahi N, et al. Soils selenium level and esophageal cancer: An ecological study in a high risk area for esophageal cancer. J Trace Elem Med Biol. 2010; 24(3): 174-7. doi: 10.1016/j.jtemb.2010.03.002.

105. Keshavarzi B, Moore F, Najmeddin A, Rahmani F. The role of selenium and selected trace elements in the etiology of esophageal cancer in high risk Golestan province of Iran. Sci Total Environ. 2012; 433: 89-97. doi: 10.1016/j.scitotenv.2012.04.033.

106. Rahimzadeh-Barzoki H, Joshaghani H, Beirami S, Mansurian M, Semnani S, Roshandel G. Selenium levels in rice samples from high and low risk areas for esophageal cancer. Saudi Medical Journal. 2014; 35(6): 617-20.

107. Steevens J, van den Brandt PA, Goldbohm RA, Schouten LJ. Selenium status and the risk of esophageal and gastric cancer subtypes: the Netherlands cohort study. Gastroenterology. 2010;138(5):1704-13.

108. Hashemian M, Murphy G, Etemadi A, Poustchi H, Brockman JD, Kamangar F, et al. Toenail mineral concentration and risk of esophageal squamous cell carcinoma, results from the Golestan Cohort Study. Cancer medicine. 2017;6(12):3052-9.

109. Lin T, Liu T, Lin Y, Zhang C, Yan L, Chen Z, et al. Serum levels of chemical elements in esophageal squamous cell carcinoma in Anyang, China: a casecontrol study based on machine learning methods. BMJ open. 2017; 7(9): e015443.

110. Cai L, Mu L-N, Lu H, Lu Q-Y, You N-CY, Yu S-Z, et al. Dietary selenium intake and genetic polymorphisms of the GSTP1 and p53 genes on the risk of esophageal squamous cell carcinoma. Cancer Epidemiol Biomarkers Prev. 2006; 15(2): 294-300. 
111. Hashemi SM, Mashhadi M, Moghaddam AA, Yousefi J, Mofrad $\mathrm{AD}$, Sadeghi $\mathrm{M}$, et al. The relationship between serum selenium and zinc with gastroesophageal cancers in the southeast of Iran. Indian J Med Paediatr Oncol. 2017; 38(2): 169-172. doi: 10.4103/ijmpo.ijmpo_83_16.
112. Pritchett NR, Burgert SL, Murphy GA, Brockman JD, White RE, Lando J, et al. Cross sectional study of serum selenium concentration and esophageal squamous dysplasia in western Kenya. BMC cancer. 2017; 17(1): 835. doi: 10.1186/s12885-017-3837-9. 